\title{
A New Species of Cyrtopodium (Orchidaceae) from the Cerrado of Central Brazil
}

\author{
João A. N. Batista and Luciano de Bem Bianchetti \\ Embrapa Recursos Genéticos e Biotecnologia, Parque Estação Biológica, \\ Final Av. W5 Norte, CP 02372, Brasília, DF, 70770-901, Brazil. \\ janb@cenargen.embrapa.br; bianchet@cenargen.embrapa.br
}

Abstract. Cyrtopodium macedoi, a new species (Orchidaceae, Cymbidieae, Cyrtopodiinae) from the cerrado vegetation of central Brazil, is described and illustrated. The species was first collected in 1951 but was subsequently misidentified as $C$. vernum. The principal distinctive character for $C$. macedoi is the basal portion of the corolla lip and the region between the lateral lobes, which is strongly deflexed and almost parallel to the lip midlobe. Cyrtopodium macedoi appears to be rare and so far known only from two sites in the Triângulo Mineiro region of the western part of the state of Minas Gerais in southeastern Brazil.

Resumo. Cyrtopodium macedoi, uma nova espécie (Orchidaceae, Cymbidieae, Cyrtopodiinae) do Cerrado do Brasil central, é descrito e ilustrado. A espécie foi coletada pela primeira vez em 1951, mas identificada erroneamente como C. vernum. A principal característica distintiva da espécie é a base e a região da corola entre os lobos laterais do labelo fortemente deflexa, quase paralela ao lobo mediano. A espécie parece ser rara e até o momento, conhecida de apenas duas localidades na região do Triângulo Mineiro, no oeste estado de Minas Gerais, no sudeste do Brasil.

Key words: Brazil, cerrado, Cymbidieae, Cyrtopodiinae, Cyrtopodium, Orchidaceae.

Cyrtopodium R. Brown, a Neotropical genus that ranges from southern Florida to northern Argentina, contains about 45 species, 36 of which occur in Brazil. The center of diversity of the genus is the Brazilian cerrado vegetation, where about 28 species occur. The cerrado is a species-rich savanna vegetation covering 2 million $\mathrm{km}^{2}$ of central Brazil (Ratter et al., 1997). A particularly Cyrtopodium-rich area is the "Distrito Federal" or Federal District, located in the cerrado core region, where 18 taxa are known (Batista \& Bianchetti, 2003).

Cyrtopodium includes primarily terrestrial and a few epiphytic and lithophytic species and occupies a broad range of habitats, including open grasslands, typical cerrado (savanna-like) vegetation, dry rocky slopes, and humid to permanently wet areas. Despite the showy flowers of many species, most of the species are unknown to horticulturists and are rarely seen in cultivation. This situation has somewhat changed in recent decades with the increasing human occupation of the cerrado, which has made access to these plants easier. As a consequence, interest in the cultivation of this genus among hobbyists has grown in recent years, at least locally in central Brazil.

The main taxonomic references for Cyrtopodium are those of Cogniaux (1898-1902) in Flora Brasiliensis and Hoehne (1942) in Flora Brasilica. Warming (1884) and, more recently, Menezes (2000) have provided color illustrations and observations about the habitat and ecological preferences of the species.

During the examination of dried specimens of Cyrtopodium in most Brazilian herbaria (ALCB, BHCB, BOTU, CEN, CESJ, CPAP, CVRD, EAC, EAN, ESA, HB, HBR, HEPH, HRCB, HUEFS, HUFU, IBGE, ICN, MBM, OUPR, PACA, R, RB, SP, SPF, UEC, UFG, UB, $\mathrm{UPCB}$ ) as part of an ongoing revision of the genus by the authors, we encountered a taxon represented by a single collection from southeastern Brazil that we were unable to assign to any known species in the genus. The resampling and examination of living specimens from the same site, 52 years after the original collection, have now shown that this taxon belongs to a new species described here as $C$. macedoi.

Cyrtopodium macedoi J. A. N. Batista \& Bianchetti, sp. nov. TYPE: Brazil. Minas Gerais: Mun. Ituiutaba, flowered in cultivation in Brasília from Sep. to early Oct. 2003, J. A. N. Batista \& L. B. Bianchetti 1306 (holotype, CEN; isotypes, K, MO, RB, SP). Figures 1, 2.

Cyrtopodium macedoi partibus vegetativis $C$. caiapoensi $\mathrm{L}$. C. Menezes simile, morphologia florali $C$. poecilo Reichenbach f. \& Warming simile et florum colore C. pallido Reichenbach f. \& Warming simile, sed a his et ab omnibus speciebus generis basi labelli et parte intra lobos laterales fortiter deflexa, fere parallele ad basim lobi centralis disposita et calo erecto, integro, paulo vel non verrucoso, omnino disposito in basi lobi centralis labeli differt. 
Terrestrial herb; pseudobulbs completely buried to partially exposed, small, oblong, apex acute, leafless from the second year onward, externally whitened, 6$11 \times 0.8-2.3 \mathrm{~cm}$; roots numerous, $3.5-4 \mathrm{~mm}$ wide, glabrous. Leaves at flowering 6 to 9 , partially to well developed, (13)20-41 × (0.5)0.7-1(1.4) cm, base with 4 or 5 sheaths, when fully developed 9 to 12 , erect, coriaceous, linear to linear-lanceolate, the more developed 37-68 × 1-1.9 cm, articulate, the articulation $2.5-4 \mathrm{~cm}$ from the apex of the pseudobulb, apex acuminate. Inflorescence lateral, erect, simple to branched, 24-37 cm long, ca. $0.5 \mathrm{~cm}$ diam., green; peduncle $11-22 \mathrm{~cm}$, with 2 sheath-like bracts, adpressed, 1.7-3.6 × 1-1.3 cm, straw colored; rachis 12-14 cm long; lateral branches none to 2 , short, 4$5.5 \mathrm{~cm}$ long; floral bracts well developed, broadly lanceolate, deflexed, ca. same size or a little longer than the pedicellate ovary, $19-28 \times 9-12 \mathrm{~mm}$, apex acute, margins slightly undulate, green with brownish-purple spots; ovary with pedicel 16-23 mm long, perpendicular to the rachis, green to greenish-brown. Flowers ca. 15, slightly sweet-scented; sepals and petals outspread, concave, margins smooth, toward the apex undulate, apex minutely apiculate, green with brown or brownishpurple spots; sepals broadly lanceolate to broadly elliptical; dorsal sepal 14-27 × 9-11.5 mm; lateral sepals slightly oblique, $14-26 \times 9-11 \mathrm{~mm}$; petals obovate to almost orbicular, base cuneate, apex obtuse to rotundate, 10-19 × 9-10 mm; lip 3-lobed, 9.5$12 \mathrm{~mm}$ long, when spread 14-19 mm wide between the apex of the side lobes; base shortly unguiculate, ca. $2 \mathrm{~mm}$ long, white; base and region between the lateral lobes strongly deflexed, almost parallel to the central lobe base; lateral lobes erect, inner surface bent ca. $45^{\circ}$ frontward toward the apex, obovate-oblong, falcate to linear falcate, $6-8 \times 2.5-5 \mathrm{~mm}$, apex rounded, base slightly to evidently constricted, margins entire, smooth, pinkish; callus entire, little to no verrucosities, then smooth, protruding, erect, completely placed at the base of the midlobe, not expanded between the lateral lobes, upper surface slightly sulcate, whitened; isthmus separating the lateral lobes from the midlobe evident; midlobe with a 1-3 mm long base, somewhat reniform to transversely elliptic, 6-8 $\times 9-12 \mathrm{~mm}$, base constricted, apex retuse when flattened, lateral margins revolute, smooth, whitened with a few pink dots at the center and a broad pinkish strip at the margin; column erect, arcuate, trigonous, 6-8 mm long, 3.5-4 mm wide at apex, apiculate, base whitened, at middle white-lilac and toward the apex green to greenish-purple; column foot 4-5 mm long; anther 2.5-3 × 1.5-1.8 mm, yellow, apex green; pollinia two, waxy, sulcate, each ca. $1 \mathrm{~mm}$ long and $0.9 \mathrm{~mm}$ wide, yellow; stipe triangular, hyaline, ca. $1.3 \mathrm{~mm}$ wide at base. Fruit not examined.
Etymology. The new species is named in honor of Amaro Macedo, who first collected the species in 1951 and whose intensive collecting in the Triângulo Mineiro region has contributed greatly to our knowledge of the flora of this region.

Distribution. Cyrtopodium macedoi is so far known only from two sites in the municipality of Ituiutaba, in the Triângulo Mineiro region in the western part of the state of Minas Gerais in southeastern Brazil. Little is left of the original native vegetation in the area. However, because of the existence of other regions with a similar vegetation and climate in the cerrado biome of central Brazil, this species should also be expected at other localities, most probably in the cerrado core region. According to the current knowledge of the species and using the World Conservation Union Red List Categories and Criteria (IUCN, 2001), C. macedoi can tentatively be classified as endangered.

Habitat, ecology, and phenology. Cyrtopodium macedoi appears to be typical of dry habitats and was found growing in dry campo limpo (grassy field) and campo sujo (dry grass-herb-subshrub field) vegetation. Plants were found growing on deep clay latosols and in shallow, rocky soil on hillsides. In the former case, the plants were vegetatively more developed and had pseudobulbs that were completely buried, while in the latter case, the plants were smaller and had the pseudobulbs partially to sometimes almost completely exposed. Cyrtopodium poecilum Reichenbach f. \& Warming, C. cristatum Lindley, C. brandonianum Barbosa Rodrigues, and C. caiapoense L. C. Menezes are sympatric species found in similar habitats. Like most Cyrtopodium species in central Brazil, C. macedoi flowers during the beginning of the rainy season in October, but probably also extends into late September and early November. As with other terrestrial species of the genus, flowering in C. macedoi is greatly enhanced by fire (Oliveira et al., 1996). In 2002 and 2003, not a single flowering plant was found during field excursions to the two sites where the species is known to occur. However, plants collected from the same sites in 2002 and kept under cultivation flowered profusely when submitted to a controlled fire in 2003 (five out of seven plants flowered after they were burned). In the label from the collection Macedo 3385, there is no mention of fire, but the ends of the leaves are dry and partially missing, suggesting that they may have been affected by fire at an early stage of development.

Cyrtopodium macedoi was first collected by Amaro Macedo in 1951, and it was through this single collection that we became aware of the existence of this species. The first excursion to the original site of 


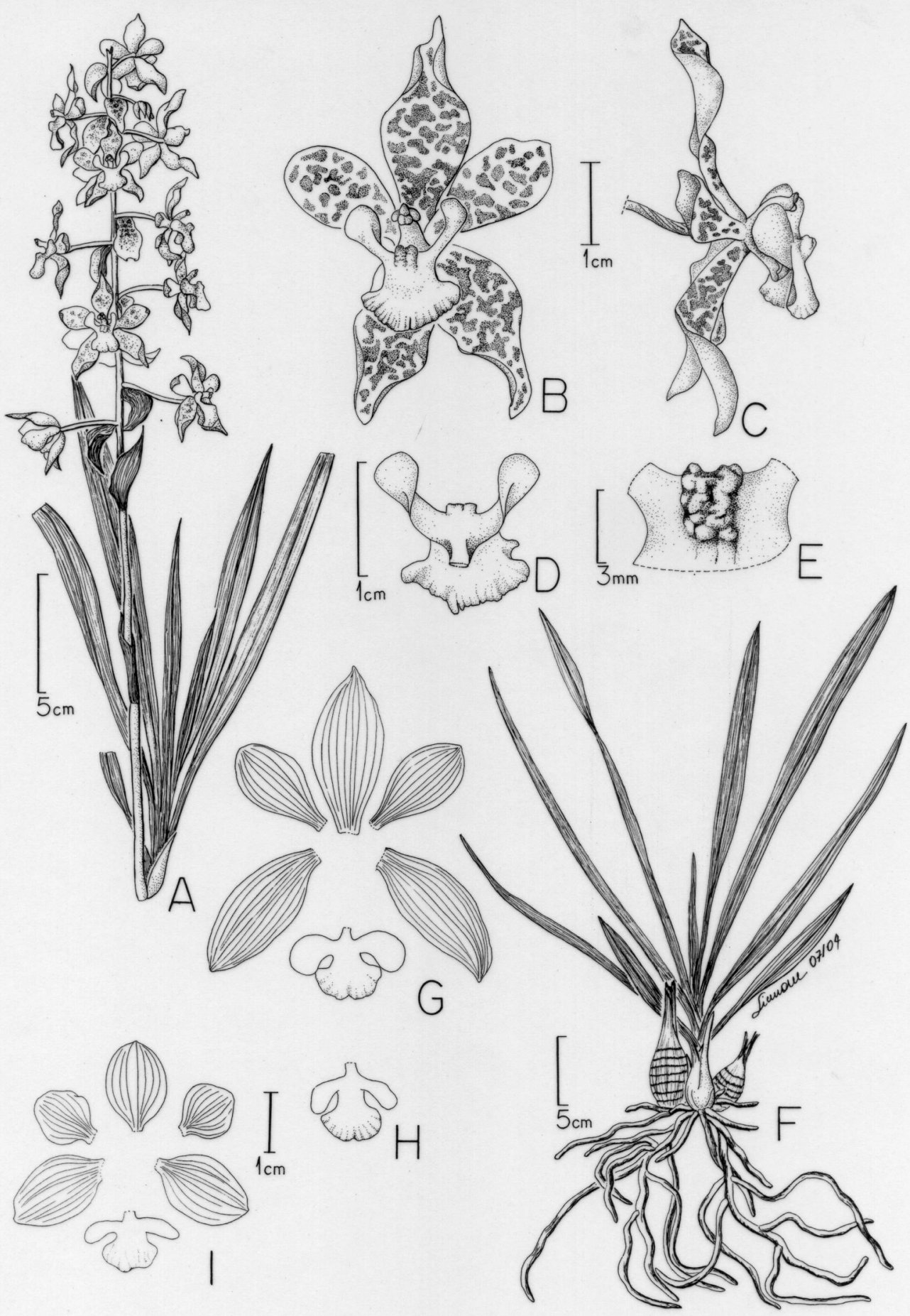

Figure 1. Cyrtopodium macedoi J. A. N. Batista \& Bianchetti. - A. Inflorescence and leaves at anthesis. -B. Flower, front view. - C. Flower, side view. -D. Lip, back view. -E. Callus. - F. Habit, about 1 to 2 months after the flowering period. - G. Perianth. - H. Variation in lip morphology. - I. Variation in perianth. Drawn from the type collection, Batista \& Bianchetti 1306, except H and I (Macedo 3385) by Simone C. Souza e Silva. 


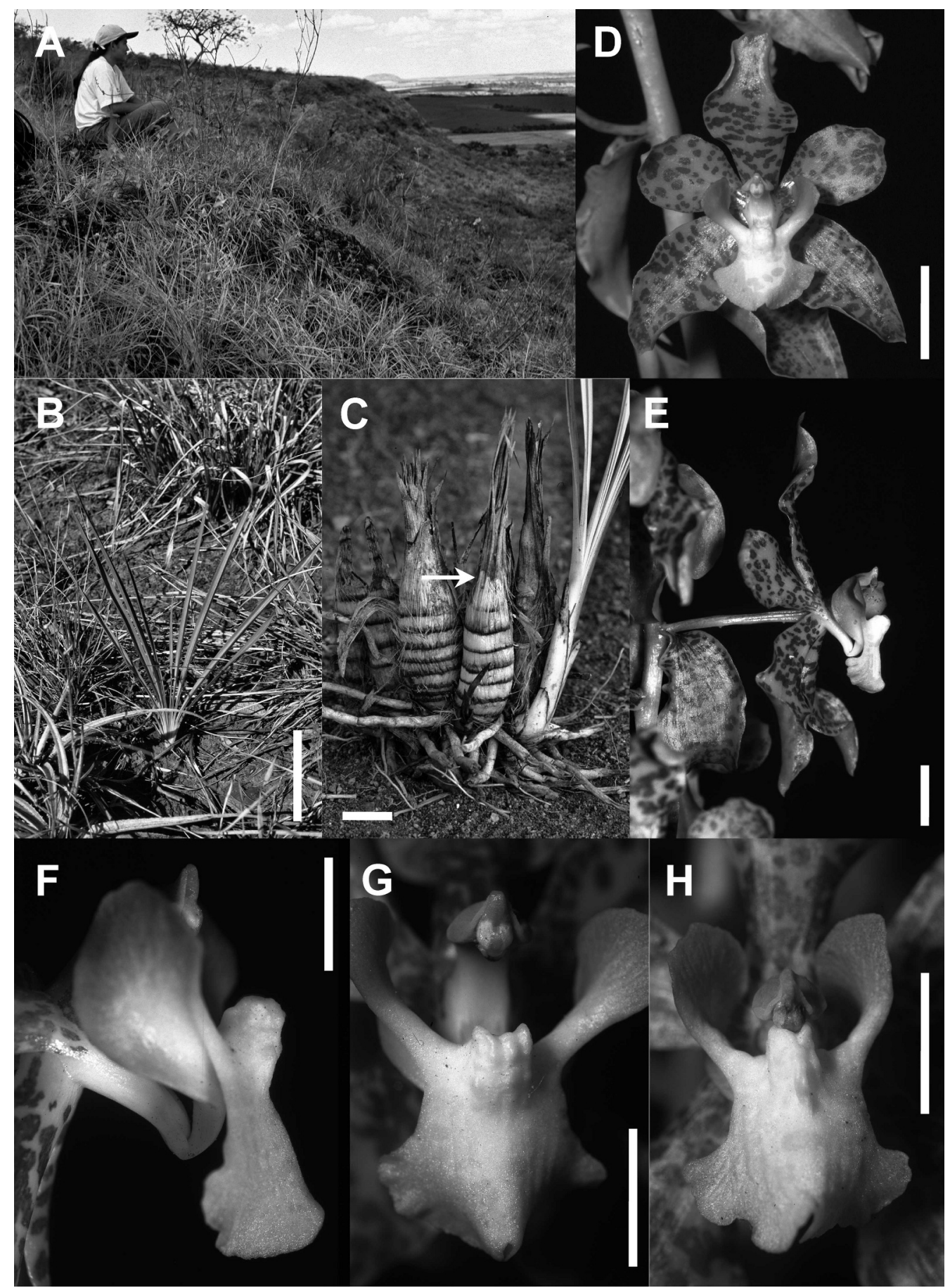

Figure 2. Cyrtopodium macedoi J. A. N. Batista \& Bianchetti. - A. Habitat. Rocky slopes with dry campo limpo, and adjacent campo sujo; unburned site at the type locality photographed at the beginning of the rainy season. - B. Habit, nonflowering plant in its habitat about the time of flowering, in late October. - C. Pseudobulbs, from an uprooted plant. The arrow indicates the approximate position the pseudobulbs were buried. —D. Flower, front view. —E. Flower, side view. —F. Lip, side view. Note the strongly deflexed base of the lip. — G. Lip and column, front view. — H. Lip and column in old flower, front view. Note that the anther touches and rests over the callus. Scale bars $=10 \mathrm{~cm}(\mathrm{~B}), 2 \mathrm{~cm}(\mathrm{C}), 1 \mathrm{~cm}(\mathrm{D}, \mathrm{E})$, and $5 \mathrm{~mm}(\mathrm{~F}-\mathrm{H})$. Photographed from living specimens of the type collection (Batista \& Bianchetti 1306). 
collection revealed several plants, but none in flower. Only after some specimens kept under cultivation at Embrapa Recursos Genéticos e Biotecnologia in Brasília had flowered and after a detailed examination of the fresh flowers was it possible to positively recognize this taxon as a new species. The collection made by Amaro Macedo (Macedo 3385) was examined by the late orchidologist F. C. Hoehne, who mistakenly identified the species as $C$. vernum Reichenbach f. \& Warming. Marcela I. Sánchez, who examined a duplicate of the Amaro Macedo collection located at the United States National Herbarium (US), identified it as C. vernum var. ligulatum. However, as far as we could determine, this variety was never published. Furthermore, C. macedoi is certainly not a variety of $C$. vernum and even if it was, according to the International Code of Botanical Nomenclature (Greuter et al., 2000), in no case does a name have priority outside the rank in which it was published (Art. 11.2).

A very distinctive character of Cyrtopodium macedoi that is not found in any other species in the genus is the base and the part between the lateral lobes of the corolla lip, which is strongly deflexed and almost parallel to the lip midlobe. Also, the callus of C. macedoi is uncommon in the genus because it shows little or no verrucosities, is protruding, and is completely placed at the base of the lip midlobe, whereas in most other species it is usually strongly verrucose, spread between the lateral lobes, and frequently reaches the claw.

Compared to other species in the genus, Cyrtopodium macedoi is similar to and can be easily confused in vegetative characters to $C$. caiapoense. However, $C$. caiapoense has brownish sepals and petals with strongly undulated margins, a shorter and less evident isthmus separating the lip lateral lobes from the midlobe, and non-falcate lateral lobes of the corolla lip. In flower morphology and color, C. macedoi is similar to $C$. poecilum, particularly to $C$. poecilum var. roseum J. A. N. Batista \& Bianchetti, which has a pink lip. However, C. poecilum has externally reddishpurple pseudobulbs, fewer $(5$ or $6(7))$ and broader $(0.8-5.5 \mathrm{~cm})$ leaves, parallel lateral lobes of the lip, and a larger callus that is deeply sulcate and extends until the base of the lip. Cyrtopodium macedoi is also similar in the morphology and color of the flowers to C. fowliei L. C. Menezes, but the latter species is from seasonally humid places (from southeastern Brazil to Venezuela), has smaller pseudobulbs $(3-5 \times 1-$ $2.5 \mathrm{~cm})$ that are externally reddish-purple, has fewer (4 to 6) leaves, and has shorter (4-5(6) $\times(4) 5-6(7)$ $\mathrm{mm})$, parallel, and non-falcate lateral lobes of the lip. In the general color of the flowers, C. macedoi is similar to C. pallidum Reichenbach f. \& Warming, but the latter species is typically from dark, sandyclay soil found in wetter areas and has smaller pseudobulbs $(2.5-3.5 \times 0.8-1 \mathrm{~cm})$, fewer $(4$ to 6$)$ leaves, an invariably simple inflorescence, and smaller flowers (sepals (8)10-11(13) × 6-8(11) $\mathrm{mm})$. Finally, C. vernum, with which $C$. macedoi was previously confused, has larger $(7-18 \times 1.5-$ $4 \mathrm{~cm}$ ) and typically exposed pseudobulbs, a more branched inflorescence with $(0) 2$ to $3(4)$ lateral branches (5)8.5-20(22) cm long, flowers that are yellow with red dots at the margins of the petals and sepals, and oblong, non-falcate lateral lobes of the lip.

In older flowers of Cyrtopodium macedoi, the column bends down or the lip moves up so that the pollinarium at the column apex touches and rests over the callus, fitting exactly into the depression in the center of the callus (Fig. 2H). In 24 years of collecting and examining hundreds of living specimens and flowers of several species, we have not seen anything similar to this arrangement in any other species of the genus. The significance of this organization is unknown.

Paratypes. BRAZIL. Minas Gerais: Ituiutaba, 28 Oct. 1951, A. Macedo 3385 (SP, US); Mun. Ituiutaba, 25 Oct. 2003, J. A. N. Batista, K. F. Pellizzaro, M. C. D. Macedo \& J. B. Santos 1441 (CEN, K, MO, RB, SP).

Acknowledgments. The authors thank Amaro Macedo and his daughter, Maria do Carmo D. Macedo, for logistical support and for their assistance during our excursions to Ituiutaba. We also thank the curator of SP for loans, Simone C. Souza e Silva for preparing the illustration, Tarciso Filgueiras for the Latin diagnoses, Stephen Hyslop for reviewing the English, and Victoria Hollowell and three anonymous reviewers for improvements in the manuscript.

\section{Literature Cited}

Batista, J. A. N. \& L. B. Bianchetti. 2003. Lista atualizada das Orchidaceae do Distrito Federal, Brasil. Acta Bot. Brasil. 17(2): 183-201.

Cogniaux, A. 1898-1902. Orchidaceae II. Cyrtopodium. Pp. 356-375 in C. F. P. Martius, A. G. Eichler \& I. Urban (editors), Flora Brasiliensis. Vol. 3, Part 5. R. Oldenbourg, Munich.

Greuter, W., J. McNeill, F. R. Barrie, H. M. Burdet, V. Demoulin, T. S. Filgueiras, D. H. Nicolson, P. C. Silva, J. E. Skog, P. Trehane, N. J. Turland \& D. L. Hawksworth (editors). 2000. International Code of Botanical Nomenclature (Saint Louis Code). Regnum Veg. 138.

Hoehne, F. C. 1942. Orchidaceas. Cyrtopodium. Pp. 8-35, tab. 4-23 in F. C. Hoehne (editor), Flora Brasilica. Vol. 12, Part 6. Secretaria da Agricultura, Indústria e Comércio de São Paulo, São Paulo.

IUCN. 2001. IUCN Red List Categories and Criteria. Version 3.1. Prepared by the IUCN Species Survival Commission. IUCN, Gland, Switzerland. 
Menezes, L. C. 2000. Genus Cyrtopodium: Espécies brasileiras., Ed. IBAMA, Brasília.

Oliveira, R. S., J. A. N. Batista, C. E. B. Proença \& L. B. Bianchetti. 1996. Influência do fogo na floração de espécies de Orchidaceae em cerrado. Pp. 61-67 in Anais do Simpósio Impacto das Queimadas sobre os Ecossistemas e Mudanças Globais. $3^{\circ}$ Congresso de Ecologia do Brasil, Brasília-DF.
Ratter, J. A., J. F. Ribeiro \& S. Bridgewater. 1997. The Brazilian cerrado vegetation and threats to its biodiversity. Ann. Bot. 80: 223-230.

Warming, E. 1884. Symbolae ad floram Brasiliae centralis cognoscendam. Part. 30. Orchideae 2. Videnskabelige Meddelelser fra den naturhistoriske Forening i Kjöbenhavn 5-8: 86-99. 